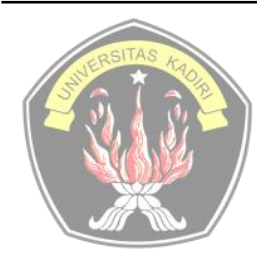

Tersedia online di

"http://ojs.unik-kediri.ac.id/index.php/ekonika"

\title{
Analisis Pengaruh Faktor Psikologis Wisatawan Pada Keputusan Berkunjung
}

\author{
Cokorda Krisna Yudha1, I Gusti Agung Prama Yoga², I Made Chandra Mandira ${ }^{3}$ \\ 1,2Fakultas Ekonomi dan Bisnis Universitas Warmadewa, \\ ${ }^{3}$ Fakultas Ekonomi dan Bisnis Universitas Pendidikan Nasional \\ Email: 1yudhacokkrisna@gmail.com, 22pramayoga13@gmail.com, \\ 3imadechandramandira@gmail.com
}

\section{Artikel History:}

Artikel masuk : 01-06-2021

Artikel revisi : 26-08-2021

Artikel diterima : 29-08-2021

\section{Keywords:}

Faktor Psikologis; Keputusan

Berkunjung

\section{Keywords:}

Psychological Factors, Visit Decision.

\begin{abstract}
ABSTRAK
Bali adalah salah satu barometer pariwisata di Indonesia yang turut menopang perekonomian Indonesia. Berbagai langkah strategis dilakukan untuk menarik kunjungan wisatawan ke Bali. Minat akan menimbulkan pertimbangan bagi seorang wisatawan untuk melakukan berbagai keputusan wisata salah satunya keputusan berkunjung. Keputusan berkunjung dapat dipengaruhi oleh beberapa faktor salah satunya dipengaruhi oleh faktor psikologis wisatawan selaku konsumen. Faktor psikologis adalah proses intern seseorang yang ada dalam diri konsumen itu sendiri yang terdiri dari motivasi, persepsi, sikap, pembelajaran dan kepribadian yang memiliki pengaruh yang sangat kuat terhadap konsumen dalam pengambilan keputusan pembelian yang dalam penelitian ini adalah pengambilan keputusan berkunjung. Pengumpulan data dilakukan dengan metode kuesioner yang dibagikan kepada para responden. Responden penelitian ini adalah wisatawan domestik yang mengunjungi Museum Neka Tahun 2020. Berdasarkan atas hasil analisis data menggunakan analisis regresi linear berganda, diperoleh hasil bahwa motivasi, sikap, persepsi, dan kepribadian berpengaruh positif dan signifikan pada keputusan berkunjung. Variabel pembelajaran tidak berpengaruh signifikan pada keputusan berkunjung
\end{abstract}

\section{ABSTRACT}

Bali is one of the tourism barometers in Indonesia which also supports the Indonesian economy. Various strategic steps were taken to attract tourist visits to Bali. Interest will lead as consideration for a tourist to make various tourism decisions, one of which is visiting decisions. The decision to visit can be influenced by several factors, one of them is influenced by psychological factors of tourist as a consumer. Psychological factors are a person's internal processes that exist within the consumer itself which consists of motivation, perception, attitude, learning and personality that have a very strong influence on consumers in making purchasing decisions which in this study are visiting decision making. Data collection was carried out by using a questionnaire method which was distributed to the respondents. 


\begin{abstract}
Respondents of this study were domestic tourists who visited the Neka Museum in 2020. Based on the results of data analysis using multiple linear regression analysis, it was found that motivation, attitudes, perceptions, and personality had a positive and significant effect on visiting decisions. Learning variables do not have a significant effect on visiting decisions.
\end{abstract}

\title{
PENDAHULUAN
}

Pariwisata merupakan salah satu sektor yang berperan penting bagi perekonomian Indonesia. Bali adalah salah satu barometer pariwisata di Indonesia yang turut menopang perekonomian Indonesia melalui sumbangan devisa dari sektor pariwisata. Berbagai langkah strategis dilakukan untuk menarik kunjungan wisatawan ke Bali. Aktifitas pariwisata merupakan suatu usaha yang dihasilkan dengan tujuan untuk menyediakan barang dan jasa yang diperlukan saat berwisata oleh para wisatawan.Kumpulan usaha yang mendukung aktifitas pariwisata adalah industri perhotelan, industri rumah makan, tempat wisata, dan lain sebagainya (Wahyuni H., Yusri Abdillah, 2015). Berbagai tempat wisata menjadi daya tarik tersendiri bagi para wisatawan. Daya tarik ini yang kemudian menumbuhkan minat wisatawan untuk berkunjung. Minat merupakan pernyataan psikis yang belum dapat diamati secara langsung, yang dapat diamati adalah dinamikanya atau manifestasinya dalam perbuatan atau tingkah laku seseorang. Minat juga dapat membantu seseorang untuk memutuskan apakah ia akan melaksanakan aktifitas yang akan ia lakukan atau tidak.

Minat akan menimbulkan pertimbangan bagi seorang wisatawan untuk melakukan berbagai keputusan wisata salah satunya keputusan berkunjung. Adapun beberapa tahapan ketika seseorang ingin mengambil suatu keputusan dalam melakukan konsumsi suatu barang atau jasa, yaitu yang pertama dengan mendapatkan informasi, kedua dengan melakukan pertimbangan terhadap informasi yang telah masuk, kemudian yang terakhir melakukan pengambilan keputusan (Wahyuni H., Yusri Abdillah, 2015). Keputusan berkunjung dapat dipengaruhi oleh beberapa faktor salah satunya dipengaruhi oleh faktor psikologis wisatawan selaku konsumen. Faktor psikologis adalah proses intern seseorang yang ada dalam diri konsumen itu sendiri yang terdiri dari motivasi, persepsi, sikap, pembelajaran dan kepribadian yang memiliki pengaruh yang sangat kuat terhadap konsumen dalam pengambilan keputusan pembelian. Faktor psikologis konsumen termasuk ke dalam perilaku konsumen yang harus dipahami oleh setiap pihak yang ada dalam industri pariwisata. Pemahaman yang tepat atas perilaku konsumen membuat penyedia produk dan jasa dalam industri pariwisata dapat mengetahui kebutuhan dan keinginan wisatawan. Pengetahuan ini dapat dijadikan dasar bagi 
para penyedia produk dan jasa untuk menarik wisatawan agar terjadi keputusan pembelian ataupun keputusan berkunjung.

Motivasi merupakan kebutuhan yang cukup mendorong seseorang untuk bertindak. Persepsi dapat diartikan sebagai proses yang digunakan untuk memilih, mengorganisasikan dan mengartikan suatu informasi untuk menciptakan suatu gambaran bagi seseorang. Persepsi yang dibentuk dipengaruhi oleh pikiran dan lingkungan sekitarnya. Pemahaman terhadap motivasi dan persepsi wisatawan diyakini mampu membantu dalam memahami kebutuhan wisatawan agar terjadi keputusan pembelian dan keputusan berkunjung. Selain itu, sikap, pembelajaran, dan kepribadian wisatawan turut dapat mempengaruhi pengambilan keputusan berkunjung individu yang bersangkutan. Rendahnya pemahaman terhadap kebutuhan psikologis wisatawan akan berdampak pada penurunan jumlah wisatawan ke daerah yang bersangkutan. Penurunan jumlah wisatawan akan berpengaruh pada penurunan pendapatan daerah. Fasilitas wisata merupakan salah satu kebutuhan wisatawan yang diyakini mampu menunjang peningkatan kunjungan wisatawan. Salah satu kondisi tempat wisata di Indonesia yaitu di Labuan Bajo yang merupakan salah satu tujuan wisata belum memiliki fasilitas penyebrangan yang memadai sehingga dapat menghambat kunjungan wisatawan. Hal tersebut menyebabkan pemerintah daerah berinisiatif untuk melakukan pembangunan dermaga penyebrangan serta beberapa area komersil dan hotel. Proses evaluasi ini penting sebagai bahan untuk terus melakukan perbaikan bagi daerah wisata tersebut.

Ubud merupakan salah satu daerah wisata yang ada di Provinsi Bali. Ubud lebih dikenal dengan daerah yang penuh akan seni dan budaya. Banyak aktivitas kepariwisataan yang telah disediakan di Ubud, sehingga wisatawan dapat mempertimbangkan Ubud sebagai salah satu destinasi tujuan wisatanya (Christine Pratama et al., 2016). Museum Neka adalah salah satu tempat wisata yang ada di Ubud yang menampilkan berbagai macam benda-benda kesenian dan berfilosofi seperti lukisan, keris, patung, dan beberapa benda lainnya. Adapun tingkat kunjungan wisatawan ke Museum Neka selama tiga tahun terakhir adalah sebagai berikut.

Tabel 1. Data Kunjungan Wisatawan ke Museum Neka

\begin{tabular}{|c|c|c|c|}
\hline Keterangan & 2016 & 2017 & 2018 \\
\hline $\begin{array}{c}\text { Museum } \\
\text { Neka }\end{array}$ & 17.113 & 13.384 & 9.594 \\
\hline
\end{tabular}

Sumber: Dinas Pariwisata Propinsi Bali, (2019). 
Pada tabel 1 dapat dilihat bahwa tingkat kunjungan wisatawan mengalami penurunan dalam kurun waktu tiga tahun terakhir. Penurunan kunjungan salah satunya dapat disebabkan oleh tidak terpenuhinya keinginan psikologis wisatawan yang bersangkutan pada daerah tujuan wisata. Sebagai contoh yaitu kurangnya sarana dan prasarana penunjang, kurangnya promosi, penilaian atas proses evaluasi wisatawan lain yang kurang baik terhadap daerah tujuan wisata, dan aspek lainnya diyakini mampu menyebabkan turunnya motivasi wisatawan untuk melakukan kunjungan. Kesenjangan penelitian ini adalah harapan yang dimiliki oleh tujuan wisata Museum Neka adalah peningkatan kunjungan wisatawan, namun pada kenyataanya yang terjadi adalah penurunan kunjungan dengan jumlah yang cukup signifikan dalam kurun waktu tiga tahun terakhir. Berdasarkan atas permasalahan tersebut, peneliti ingin melakukan konfirmasi apakah faktor internal psikologis wisatawan memiliki pengaruh pada saat wisatawan mengambil keputusan berkunjung ke Museum Neka. Penelitian ini dilakukan mengetahui pengaruh faktor internal psikologis wisatawan yaitu motivasi, persepsi, sikap, pembelajaran, dan kepribadian pada pengambilan keputusan berkunjung. Hal ini sangat penting diketahui sebagai bahan pertimbangan untuk melakukan pengelolaan sumber daya di bidang pariwisata. Hasil penelitian diharapkan mampu menjadi pertimbangan bagi para pengelola daerah wisata mengenai faktor-faktor yang dapat mempengaruhi pengambilan keputusan berkunjung wisatawan, sehingga dapat menjadi bahan evaluasi dalam pengelolaan daerah wisatanya.

Berdasarkan latar belakang yang telah dipaparkan sebelumnya, maka dapat dirumuskan masalah penelitian sebagai berikut.

1) Apakah variabel motivasi berpengaruh signifikan pada pengambilan keputusan berkunjung?

2) Apakah variabel persepsi berpengaruh signifikan pada pengambilan keputusan berkunjung?

3) Apakah variabel sikap berpengaruh signifikan pada pengambilan keputusan berkunjung?

4) Apakah variabel pembelajaran berpengaruh signifikan pada pengambilan keputusan berkunjung?

5) Apakah variabel kepribadian berpengaruh signifikan pada pengambilan keputusan berkunjung?

\section{TINJAUAN PUSTAKA}

\section{State of The Art Penelitian}

Terdapat beberapa penelitian sebelumnya yang turut menunjang terlaksananya penelitian ini. Pada penelitian (Husaen H, Muhammad A., 2015), yang bersangkutan menggunakan variabel independen psikologi. Variabel psikologi digambarkan sebagai satu 
variabel yang berdiri sendiri. Pada penelitian kali ini, peneliti menggunakan variabel psikologi namun bukan sebagai satu variabel yang berdiri sendiri. Variabel psikologi dikategorikan lebih rinci kedalam lima aspek yaitu motivasi, persepsi, sikap, pembelajaran dan kepribadian. Pada penelitian (Muksin \& Sunarti, 2018), yang bersangkutan menggunakan teknik pengambilan sampel purposive sampling yaitu teknik pengambilan sampel dengan menggunakan kriteria tertentu, sedangkan penelitian kali ini menggunakan teknik incidental sampling. Teknik incidental sampling mampu memberikan kesempatan yang sama bagi para wisatawan untuk menjadi responden. Para wisatawan tidak harus dikategorikan dalam kriteria tertentu, sehingga hasil yang diperoleh lebih mampu mewakili wisatawan secara umum. Adapun rangkuman dari state of the art pada penelitian ini tampilkan pada tabel dibawah ini.

\section{Tabel 2. State of The Art Penelitian}

\begin{tabular}{|c|c|c|c|c|}
\hline No & Judul Penelitian & Nama Peneliti & Metode Penelitian & Hasil Penelitian \\
\hline 1 & $\begin{array}{c}\text { Faktor-Faktor yang } \\
\text { Mempengaruhi } \\
\text { Keputusan Wisatawan } \\
\text { dalam Melakukan } \\
\text { Kunjungan Wisata di } \\
\text { Kota Tidore Kepulauan }\end{array}$ & $\begin{array}{c}\text { (Husaen } H, \\
\text { Muhammad A., } \\
\text { 2015) }\end{array}$ & $\begin{array}{c}\text { Deskriptif } \\
\text { kuantitatif dengan } \\
\text { metode } \\
\text { pengambilan data } \\
\text { dengan } \\
\text { menyebarkan } \\
\text { kuesioner. }\end{array}$ & $\begin{array}{c}\text { Hasil penelitian menunjukan } \\
\text { bahwa faktor bauran pemasaran, } \\
\text { dan psikologi berpengaruh pada } \\
\text { keputusan wisatawan dalam } \\
\text { melakukan kunjungan wisata. }\end{array}$ \\
\hline 2 & $\begin{array}{c}\text { Pengaruh Motivasi } \\
\text { Terhadap Keputusan } \\
\text { Berkunjung Wisatawan } \\
\text { di Ekowisata Mangrove } \\
\text { Wonorejo Surabaya }\end{array}$ & $\begin{array}{c}\text { (Muksin \& Sunarti, } \\
\text { 2018) }\end{array}$ & $\begin{array}{c}\text { Deskriptif } \\
\text { kuantitatif dengan } \\
\text { metode } \\
\text { pengambilan data } \\
\text { dengan } \\
\text { menyebarkan } \\
\text { kuesioner. }\end{array}$ & $\begin{array}{l}\text { Hasil penelitian menunjukan } \\
\text { bahwa motivasi fisik, motivasi } \\
\text { sosial, dan motivasi fantasi } \\
\text { berpengaruh signifikan pada } \\
\text { keputusan berkunjung wisatan. }\end{array}$ \\
\hline 3 & $\begin{array}{l}\text { Pengaruh Produk Wisata } \\
\text { Terhadap Keputusan } \\
\text { Berkunjung Wisatawan } \\
\text { di Pulau Lengkuas } \\
\text { Belitung }\end{array}$ & $\begin{array}{c}\text { (Inkky Arista, } \\
\text { Darsiharjo, 2017) }\end{array}$ & $\begin{array}{c}\text { Deskriptif } \\
\text { kuantitatif dengan } \\
\text { metode } \\
\text { pengambilan data } \\
\text { dengan } \\
\text { menyebarkan } \\
\text { kuesioner. }\end{array}$ & $\begin{array}{l}\text { Hasil penelitian menunjukan } \\
\text { bahwa produk wisata } \\
\text { berpengaruh sangat kuat pada } \\
\text { keputusan berkunjung } \\
\text { wisatawan. }\end{array}$ \\
\hline
\end{tabular}

\section{Pariwisata}

Pariwisata adalah berbagai macam kegiatan wisata dan didukung berbagai fasilitas dan layanan yang disediakan oleh masyarakat, pengusaha, Pemerintah, dan Pemerintah daerah (Undang-Undang Republik Indonesia, 2009). Pariwisata adalah perpindahan seseorang secara sementara dengan tujuan keluar dari pekerjaan-pekerjaan rutin atau keluar dari tempat kediamannya. Aktifitas wisata dilakukan di tempat yang mereka tuju dan fasilitas dibuat untuk memenuhi kebutuhan mereka di tempat wisata. (Yoeti, 1996) menyatakan bahwa pariwisata harus memenuhi empat kriteria di bawah ini, yaitu: 
1. Perjalanan dilakukan dari suatu tempat ke tempat lain, perjalanan dilakukan di luar tempat kediaman di mana orang itu biasanya tinggal.

2. Tujuan perjalanan dilakukan semata-mata untuk bersenang-senang, tanpa mencari nafkah di negara, kota atau DTW yang dikunjungi.

3. Uang yang dibelanjakan wisatawan tersebut dibawa dari negara asalnya, dimana dia bisa tinggal atau berdiam, dan bukan diperoleh karena hasil usaha selama dalam perjalanan wisata yang dilakukan.

4. Perjalanan dilakukan minimal 24 jam atau lebih. Dalam pengertian kepariwisataan terdapat empat faktor yang harus ada dalam batasan suatu definisi pariwisata. Faktorfaktor tersebut adalah perjalanan itu dilakukan dari satu tempat ke tempat lain, perjalanan itu harus dikaitkan dengan orang-orang yang melakukan perjalanan wisata semata-mata sebagai pengunjung tempat wisata.

\section{Motivasi}

(Uno, 2010) menyatakan bahwa motivasi dapat diartikan secara konseptual dan operasional. Secara konseptual motivasi adalah suatu dorongan yang dapat mempengaruhi kinerja. Sedikit atau banyak intensitas motivasi yang diberikan berpengaruh pada besar kecilnya pengaruh motivasi pada kinerja. Dari segi konseptual, dapat dikatakan bahwa motivasi merupakan suatu dorongan yang timpul baik dari luar maupun dari dalam diri sendiri untuk melakukan suatu aktivitas. Motivasi seseorang tergantung pada kekuatan motifnya. (Maduka \& Okafor, 2014) menyatakan bahwa motif dapat berupa kebutuhan dan keinginan yang dimilki individu. Motif tersebut akan mendorong seseorang untuk bertindak yang nantinya akan menentukan perilaku yang bersangkutan.

\section{Persepsi}

Persepsi dapat diartikan sebagai proses menerima atau mengambil. Terdapat dua basis dari persepsi yaitu fisiologis dan budaya, ekonomi, serta sosial. Secara fisiologis, menciptakan sebuah persepsi diawali dengan penggunaan kelima indra yang ada dalam diri seseorang. Secara budaya ekonomi, ekonomi, dan sosial proses ini, melibatkan kemampuan dalam mengorganisir dan melakukan interpretasi stimuli. Dari kedua basis tersebut, basis fisiologis merupakan basis yang memberi respon lebih cepat karena melibatkan kelima indra seseorang. Persepsi antara orang satu dengan lainnya akan berbeda dalam menanggapi suatu rangsangan. Pandangan seseorang sebagai konsumen terhadap suatu produk atau layanan jasa bisa beragam dan sangat luas. Melalui rangsangan fisik, keadaan individu, dan rangsangan yang berhubungan dengan lingkungan sekitar dapat digunakan untuk mengetahui persepsi dari seseorang (Erna, 2008). 


\section{Sikap}

(Ajzen \& Fishbein, 1970) menyatakan bahwa sikap adalah kecenderungan untuk secara konsisten memberikan tanggapan menyenangkan atau tidak menyenangkan terhadap suatu objek. Tanggapan ini timbul akibat proses belajar atau hasil dari proses evaluasi. Terdapat beberapa komponen dari sikap yaitu sebagai berikut.

1. Kognitif yaitu aspek pengetahuan tentang suatu objek.

2. Afektif yaiyu perasaan signifikan atau negatif yang berkaitan tentang pengetahuan yang dimiliki terhadap suatu objek.

3. Tingkah laku yaitu perwujudan dalam bentuk tindakan terhadap suatu objek.

(Baron \& Byrne, 2005) mengatakan bahwa hampir semua psikolog sosial yakin bahwa sikap dipelajari, dan sebagian besar diskusi tentang sikap akan berfokus pada bagaimana sikap diperoleh. Ada dua hal yang menjelaskan tentang bagaimana pembentukan sikap, yaitu sebagai berikut.

1. Pembelajaran Sosial

Salah satu cara pembentukan sikap adalah melalui proses pembelajaran sosial (social learning). Pembelajaran sosial adalah proses dimana seseorang mengadopsi informasi baru, bentuk tingkah laku, atau sikap dari orang lain. Proses ini terjadi ketika orang tersebut berinteraksi engan orang lain dan mengobservasi tingkah laku mereka.

\section{Faktor Genetik}

Sikap yang berkenaan dengan dengan tingkat kecenderungan tertentu (misal, kecenderungan menyukai jenis musik atau makanan tertentu) lebih kuat dipengaruhi oleh faktor genetik daripada sikap yang sifatnya lebih kognitif (misal, sikap terhadap peraturan). Sikap yang cenderung diturunkan lebih sulit diubah daripada sikap yang tidak diturunkan, dan sikap yang cenderung diturunkan memiliki efek yang lebih kuat pada tingkah laku.

\section{Pembelajaran}

(Solomon, 2012) menyatakan pembelajaran adalah perubahan yang relatif permanen dalam perilaku yang disebabkan oleh pengalaman, belajar adalah proses yang berkelanjutan. Dari definisi yang telah disebutkan diatas dapat diterangkan bahwa belajar merupakan perubahan perilaku yang dihasilkan dari pengalaman dan latihan termasuk didalamnya adalah perilaku mengenai pola pembelian suatu produk baik yang berupa barang maupun jasa. Pembelajaran menurut (Schiffman et al., 2012) adalah sebuah proses yang diperoleh individu 
dari pengetahuan dan pengalaman dalam membeli dan mengkonsumsi, yang mereka gunakan untuk bertindak dimasa depan.

\section{Kepribadian}

Kepribadian setiap konsumen satu dengan lainnya pasti berbeda, dibawakan dan ditunjukkannya secara unik dan khas dalam caranya bertingkah laku, kebiasaan berfikir, sikap, minat, dan pandangan hidup. Perilaku dan kepribadian setiap individu dapat berubah-ubah, karena manusia selalu belajar akan hal baru di sepanjang hidupnya. Penentuan tanggapan dan cara individu untuk memberikan respon terhadap lingkungan, dapat diamati sebagai bentuk perilaku. Teori kepribadian menyatakan bahwa perilaku dapat diprediksikan dengan memahami kepribadian. Teori ini menunjukkan bahwa perilaku dapat ditentukan oleh kepribadian seseorang (Feist \& Feist, 2013). (Alwisol, 2014) menyatakan bahwa kepribadian adalah sifat umum berupa pikiran, kegiatan, dan perasaan yang berpengaruh secara sistemik terhadap keseluruhan tingkah laku seseorang.

\section{Keputusan Berkunjung}

Keputusan berkunjung merupakan salah satu pengaplikasian dari keputusan pembelian. Konsumen dalam aktivitas berkunjung adalah wisatawan. (Amirullah, 2002) menyatakan keputusan pembelian adalah proses dimana konsumen melakukan penilaian terhadap berbagai alternatif pilihan dan memilih salah satu atau lebih alternatif yang diperlukan berdasarkan pertimbangan-pertimbangan tertentu. Menurut (Kotler \& Keller, 2009), di dalam tahap evaluasi konsumen menentukan preferensi atas merek-merek yang berada dalam kumpulan pilihannya, seorang konsumen juga dapat menentukan kecenderungan niat untuk membeli merek yang paling disukai. Menurut (Swastha \& Handoko, 2000) menjelaskan bahwa keputusan untuk membeli merupakan kumpulan dari sejumlah keputusan pembelian yang memiliki beberapa komponen yaitu keputusan tentang jenis produk, merek, penjualannya atau pilihan penyalur, jumlah produk, waktu pembelian, cara pembayaran.

\section{Hipotesis Penelitian}

\section{Motivasi berpengaruh signifikan pada pengambilan keputusan berkunjung}

Motivasi merupakan kebutuhan dan keinginan yang dimilki individu. Motif tersebut akan mendorong seseorang untuk bertindak yang nantinya akan menentukan perilaku yang bersangkutan (Maduka \& Okafor, 2014). Dorongan akan kebutuhan tersebut akan dijadikan sebagai dasar bagi wisatawan untuk menentukan pilihannya akan berkunjung ke daerah wisata 
dengan karakteristik yang diinginkan. Ketika dorongan sudah terjadi maka akan terjadi tindakan berupa pengambilan keputusan berkunjung. Apabila tidak disertai dengan motivasi, maka pengambilan keputusan pun diyakini akan sulit untuk dilakukan.

$\mathrm{H}_{1}$ : Motivasi berpengaruh signifikan pada pengambilan keputusan berkunjung.

\section{Persepsi berpengaruh signifikan pada pengambilan keputusan berkunjung}

Persepsi merupakan timbal balik atas rangsangan yang diterima oleh seorang individu. Persepsi antara orang satu dengan lainnya akan berbeda dalam menanggapi suatu rangsangan. Pandangan seseorang sebagai konsumen terhadap suatu produk atau layanan jasa bisa beragam dan sangat luas. Pandangan seseorang dapat dibentuk melalui rangsangan-rangsangan yang diterima melalui kelima indra yang dimiliki. Rangsangan ini diyakini mampu membantu seorang wisatawan untuk menentukan keputusan berkunjung. Persepsi dapat ditimbulkan salah satunya dari faktor fisiologis yaitu panca indra dari seorang individu. Panca indra tersebut akan membuat wisatawan memberikan timbal balik atas apa yang dilihat dan dirasakan ketika melakukan analisis terhadap suatu daerah tujuan wisata.

$\mathrm{H}_{2}$ : Persepsi berpengaruh signifikan pada pengambilan keputusan berkunjung

\section{Sikap berpengaruh signifikan pada pengambilan keputusan berkunjung}

Sikap adalah suatu kecenderungan yang diberikan oleh seseorang berupa tanggapan senang atau tidak senang terhadap suatu objek secara konsisten. Tanggapan ini timbul akibat proses belajar atau hasil dari proses (Ajzen \& Fishbein, 1970). Ketika seorang wisatawan memperoleh ulasan yang tidak menyenangkan terhadap suatu daerah tujuan wisata, maka yang bersangkutan akan mengambil sikap untuk tidak melakukan kunjungan ke daerah tersebut. Begitu pula sebaliknya, apabila ulasan yang diperoleh memiliki nilai yang signifikan dan menyenangkan, maka wisatawan cenderung akan menjadikan hal tersebut sebagai pertimbangan untuk melakukan keputusan berkunjung.

$\mathrm{H}_{3}$ : Sikap berpengaruh signifikan pada pengambilan keputusan brekunjung

\section{Pembelajaran berpengaruh signifikan pada pengambilan keputusan berkunjung}

(Schiffman et al., 2012) menyatakan pembelajaran merupakan suatu proses seseorang yang didapatkan dari pengalaman dan pengetahuan dalam membeli dan menggunakan suatu barang atau jasa. Pembelajaran dapat dijadikan sebagai suatu dasar bagi seorang wisatawan untuk melakukan pengambilan keputusan. Pengetahuan dan pengalaman yang didapatkan tidak hanya berasal dari diri sendiri melainkan dapat berasal dari orang atau wisatawan lain. Apabila berdasarkan hasil pembelajaran, wisatawan mengetahui bahwa beberapa individu lain memiliki 
pengalaman yang cenderung menyenangkanterhadap suatu daerah tujuan wisata maka wisatawan bisa melakukan keputusan berkunjung ke daerah tujuan wisata yang bersangkutan.

$\mathrm{H}_{4}$ : Pembelajaran berpengaruh signifikan pada pengambilan keputusan berkunjung

\section{Kepribadian berpengaruh signifikan pada pengambilan keputusan berkunjung}

(Alwisol, 2014) menyatakan kepribadian adalah sifat yang ada pada diri seseorang berupa pikiran, kegiatan, dan perasaan yang berpengaruh pada keseluruhan perilaku seseorang. Pikiran, kegiatan, dan perasaan tersebut merupakan beberapa dasar yang mampu mempengaruhi seseorang untuk melakukan suatu tindakan salah satunya keputusan berkunjung. Kepribadian seseorang dapat dijadikan sebagai dasar bagi yang bersangkutan untuk mengambil suatu keputusan. Kepribadian yang berbeda-beda menyebabkan masingmasing wisatawan memiliki karakteristik daerah tujuan wisata tersendiri sesuai dengan yang mereka butuhkan.

$\mathrm{H}_{5}$ : Kepribadian berpengaruh signifikan pada pengambilan keputusan berkunjung

\section{METODE PENELITIAN}

\section{Lokasi Penelitian}

Lokasi penelitian dilakukan pada Museum Neka yang berlokasi di Jalan Raya Sanggingan, Campuhan, Kedewatan, Kecamatan Ubud, Kabupaten Gianyar pada tahun 2020.

\section{Populasi dan Sampel Penelitian}

Populasi dalam penelitian ini adalah wisatawan domestik yang berkunjung ke Museum Neka. Setelah dilakukan perhitungan proyeksi, total populasi yang berkunjung ke Museum Neka diperkirakan sebanyak 683 wisatawan. Metode pengambilan sampel adalah dengan menggunakan teknik incidental sampling yaitu teknik pengambilan sampel berdasarkan kebetulan atau siapa saja yang ditemui peneliti saat itu. Besaran jumlah sampel pengunjung dilakukan dengan menggunakan rumus slovin yaitu sebesar 204 wisatawan.

\section{Metode Pengambilan Data}

Penelitian ini merupakan penelitian deskriptif kuantitatif. Metode pengambilan data yang digunakan adalah dengan menyebarkan kuesioner secara langsung kepada para responden. Kuesioner tersebut terdapat instrumen-instrumen yang akan digunakan untuk mengukur variabel dependen dan variabel independen dari penelitian. 


\section{Definisi Operasional Variabel}

1) Keputusan Berkunjung (Y)

(Kotler \& Keller, 2009) menyatakan bahwa dalam proses evaluasi, seorang konsumen akan menentukan kecenderungan atas merk yang telah dikumpulkan dalam pilihan-pilihannya. Yang bersangkutan akan menentukan keputusan pembelian terhadap barang atau jasa yang paling disukai. Terdapat lima instrumen utama dalam keputusan berkunjung yaitu pengenalan kebutuhan, pencarian informasi, evaluasi alternatif, pembelian, dan perilaku pasca pembelian. Terdapat 10 pertanyaan yang berkaitan dengan kelima instrumen pokok variabel keputusan berkunjung.

\section{2) Motivasi (X1)}

(Maduka \& Okafor, 2014) menyatakan bahwa motivasi adalah kebutuhan dan keinginan yang dimiliki individu. Motif tersebut akan mendorong seseorang untuk bertindak yang nantinya akan menentukan perilaku yang bersangkutan. Terdapat empat instrumen pokok motivasi yang digunakan dalam penelitian ini yaitu motivasi yang mendorong, motivasi yang yang menarik, motivasi intrinsik, dan motivasi ekstrinsik. Terdapat 18 pertanyaan yang berkaitan dengan empat instrumen pokok motivasi.

3) Persepsi (X2)

Persepsi merupakan timbal balik atas rangsangan yang diterima oleh seorang individu (Erna, 2008). Terdapat 10 pernyataan yang berkaitan dengan persepsi wisatawan yang dibagi atas persepsi dari segi fisik daerah wisata dan persepsi dari segi non fisik daerah wisata.

4) Sikap (X3)

(Ajzen \& Fishbein, 1970) menyatakan sikap adalah suatu kecenderungan yang diberikan oleh seseorang berupa tanggapan senang atau tidak senang terhadap suatu objek secara konsisten. Terdapat 5 pernyataan yang berkaitan dengan sikap wisatawan.

5) Pembelajaran (X4)

Pembelajaran merupakan suatu proses seseorang yang didapatkan dari pengalaman dan pengetahuan dalam membeli dan menggunakan suatu barang atau jasa. Pembelajaran dapat dijadikan sebagai suatu dasar bagi seorang wisatawan untuk melakukan pengambilan keputusan (Schiffman et al., 2012). Terdapat 3 pernyataan yang berkaitan dengan pembelajaran wisatawan. 
6) Kepribadian (X5)

(Alwisol, 2014) menyatakan kepribadian adalah sifat yang ada pada diri seseorang berupa pikiran, kegiatan, dan perasaan yang berpengaruh pada keseluruhan perilaku seseorang.Terdapat lima dimensi variabel yaitu ekstraversi, mudah bersepakat, sifat berhatihati, stabilitas emosi, dan terbuka terhadap hal-hal baru.

\section{Teknik Analisis Data}

Pertama-tama dilakukan uji instrument penelitian dengan menggunakan uji validitas dan uji reliabilitas. Setelah dinyatakan valid dan reliabel, akan dilanjutkan pada proses tabulasi data. Data yang ditabulasi kemudian akan dirubah menjadi data interval melalui teknik transformasi Method of Succesive Interval (MSI). Setelah data telah siap, maka akan dilanjutkan dengan melakukan uji asumsi klasik. Terdapat tiga uji asumsi klasik yang akan dilakukan yaitu uji normalitas, multikolinearitas, dan heteroskedastisitas. Setelah data dinyatakan terbebas dari asumsi klasik maka akan dilanjutkan dengan pengujian hipotesis. Hipotesis akan diuji dengan teknik analisis regresi linear berganda.

\section{HASIL DAN PEMBAHASAN}

\section{Hasil Penelitian}

\section{Deskripsi Responden}

Tabel 3. Deskripsi Responden

\begin{tabular}{|c|c|c|c|}
\hline Nomor & Keterangan & Jumlah & Persentase \\
\hline \multirow[t]{4}{*}{1} & Jenis Kelamin & & \\
\hline & Perempuan & 96 & $61 \%$ \\
\hline & Laki-Laki & 61 & $39 \%$ \\
\hline & Total & 157 & $100 \%$ \\
\hline \multirow[t]{6}{*}{2} & Usia & & \\
\hline & $<20$ Tahun & 43 & $27 \%$ \\
\hline & 21-30 Tahun & 56 & $36 \%$ \\
\hline & 31-40 Tahun & 37 & $24 \%$ \\
\hline & 41-50 Tahun & 21 & $13 \%$ \\
\hline & Total & 157 & $100 \%$ \\
\hline \multirow[t]{4}{*}{3} & Status Perkawinan & & \\
\hline & Belum Kawin & 86 & $55 \%$ \\
\hline & Sudah Kawin & 71 & $45 \%$ \\
\hline & Total & 157 & $100 \%$ \\
\hline \multirow[t]{6}{*}{4} & Tingkat Pendidikan Terakhir & & \\
\hline & SMA & 49 & $31 \%$ \\
\hline & Diploma & 11 & $7 \%$ \\
\hline & $\mathrm{S} 1$ & 82 & $52 \%$ \\
\hline & $\mathrm{S} 2$ & 15 & $10 \%$ \\
\hline & Total & 157 & $100 \%$ \\
\hline
\end{tabular}


Sumber: Data diolah (2020)

Berdasarkan atas data yang telah diperoleh, sebagian besar responden adalah perempuan. Mayoritas responden memiliki rentang usia dari 21 sampai 30 tahun. Terdapat 86 responden yang berstatus belum kawin dan sisanya sebanyak 71 berstatus sudah kawin. Sebanyak 49 responden memiliki tingkat pendidikan akhir SMA, 11 orang dengan tingkat pendidikan Diploma, 82 orang dengan tingkat pendidikan Strata 1, dan sebanyak 15 orang dengan tingkat pendidikan Strata 2.

\section{Hasil Uji Instrumen}

Seluruh instrumen penelitian telah valid dengan nilai koefisien korelasi lebih besar dari 0,3. Instrumen penelitian dianggap telah reliabel apabila nilai cronbach's alpha lebih besar dari 0,60. Berdasarkan atas hasil uji reliabilitas, diperoleh bahwa nilai cronbach's alpha masingmasing variabel motivasi, persepsi, sikap, pembelajaran, kepribadian, dan keputusan berkunjung berturut-turut sebesar 0764;0,884;0,722;0,725;0,743, dan 0,716. Berdasarkan atas hasil tersebut, maka dapat dikatakan bahwa instrument pada penelitian ini layak untuk digunakan.

\section{Hasil Uji Asumsi Klasik}

Berdasarkan hasil uji asumsi klasik, data penelitian ini dinyatakan telah bebas dari permasalahan multikolinearitas dengan nilai tolerance variabel motivasi, persepsi, sikap, pembelajaran, dan kepribadian telah diatas 0,1 yaitu 0,$947 ; 0,787 ; 0,811 ; 0,895$; dan 0,916 . Nilai VIF variabel motivasi, persepsi, sikap, pembelajaran, dan kepribadian telah dibawah 10 yaitu 1,$056 ; 1,271 ; 1,234 ; 1,117$; dan 1,091 . Data penelitian telah terdistribusi normal dengan nilai Asymp. Sig (2-Tailed) sebesar 0,386. Data penelitian juga telah terbebas dari permasalahan heteroskedastisitas dengan nilai Sig. masing-masing variabel motivasi, persepsi, sikap, pembelajaran, kepribadian berturut-turut 0,$955 ; 0,333 ; 0,120 ; 0,830 ;$ dan 0,059 .

\section{Hasil Analisis Reresi Linear Berganda}

Nilai R Square sebesar 0,502 yang artinya bahwa sebesar 50,2\% keputusan berkunjung dipengaruhi oleh variabel motivasi, persepsi, sikap, pembelajaran, dan kepribadian. Sisanya sebesar 49,8\% dipengaruhi oleh variabel lain diluar penelitian ini. Berdasarkan hasil analisis diperoleh bahwa nilai signifikansi pada uji kelayakan model adalah sebesar 0,000 yang berarti bahwa model penelitian ini layak untuk digunakan karena variabel independen mampu menjelaskan variabel dependen. 
Tabel 4. Hasil Uji Analisis Regresi Linear Berganda

Coefficients $^{a}$

\begin{tabular}{|c|c|c|c|c|c|}
\hline \multirow[t]{2}{*}{ Model } & \multicolumn{2}{|c|}{ Unstandardized Coefficients } & \multirow{2}{*}{$\frac{\text { Standardized Coefficients }}{\text { Beta }}$} & \multirow[t]{2}{*}{$t$} & \multirow[t]{2}{*}{ Sig. } \\
\hline & $\mathrm{B}$ & Std. Error & & & \\
\hline (Constant) & 14,594 & 7,013 & & $-2,081$ & 039 \\
\hline Motivasi & ,045 & ,050 &,- 05 & 899 & 007 \\
\hline Persepsi & 283 & ,084 & ,24 & 3,376 & ,001 \\
\hline Sikap & ,764 & ,121 & ,46 & 6,321 & ,000 \\
\hline Pembelajaran & 163 & 278 & 03 & ,587 &, 558 \\
\hline Kepribadian & ,796 & 174 & ,28 & 4,576 &, 000 \\
\hline
\end{tabular}

a. Dependent Variabel: Keputusan Berkunjung

\section{Pembahasan Hasil Penelitian}

\section{Pengaruh Motivasi pada Pengambilan Keputusan Berkunjung}

Hasil analisis menunjukan bahwa nilai signifikansi variabel motivasi adalah sebesar 0,007. Hal ini menunjukan bahwa motivasi berpengaruh positif dan signifikan pada pengambilan keputusan berkunjung. Hasil penelitian ini searah dengan penelitian yang dilakukan oleh (Muksin \& Sunarti, 2018). Penyedia wisata yang mampu memahami motivasi perjalanan wisatawan diyakini mampu menarik kunjungan wisatawan. Terdapat berbagai motivasi wisatawan seperti ingin mencari sesuatu yang belum diketahui, menjelajahi, wilayah baru, mencari perubahan suasana, atau untuk mendapatkan perjalanan baru (Husaen $\mathrm{H}$, Muhammad A., 2015). Dorongan akan kebutuhan tersebut akan dijadikan sebagai dasar bagi wisatawan untuk menentukan pilihannya akan berkunjung ke daerah wisata dengan karakteristik yang diinginkan. Ketika dorongan sudah terjadi maka akan terjadi tindakan berupa pengambilan keputusan berkunjung. Pemahaman terhadap motivasi wisatawan mampu membuat penyedia wisata mempersiapkan segala fasilitas dengan lebih baik untuk menarik para wisatawan. Pada Museum Neka, selain menyajikan berbagai benda kesenian, museum tersebut juga secara berkesinambungan menambah koleksi benda keseniannya setiap tahun. Museum Neka juga menampilkan bangunan yang bergaya arsitektur Bali dilengkapi dengan taman yang asri. Hal ini diyakini mampu menimbulkan dorongan bagi wisatawan untuk berkunjung ke Museum Neka.

\section{Pengaruh Persepsi pada Pengambilan Keputusan Berkunjung}


Hasil analisis menunjukan bahwa nilai signifikansi variabel persepsi adalah sebesar 0,001. Hal ini menunjukan bahwa persepsi berpengaruh positif dan signifikan pada pengambilan keputusan berkunjung. Hasil penelitian ini searah dengan temuan dari penelitian yang dilakukan oleh (Masni Nistari et al., 2016) menemukan hasil bahwa persepsi berpengaruh secara parsial terhadap keputusan berkunjung. Persepsi dapat ditimbulkan salah satunya dari faktor fisiologis yaitu panca indra dari seorang individu. Panca indra tersebut akan membuat wisatawan memberikan timbal balik atas apa yang dilihat dan dirasakan ketika melakukan analisis terhadap suatu daerah tujuan wisata (Erna, 2008). Museum Neka telah memiliki website resmi yang dapat diakses oleh masyarakat yaitu www.museumneka.com. Website ini menampilkan secara detail profil dari Museum Neka. Wisatawan yang ingin berkunjung melihat informasi yang ditampilkan dalam website, sehingga dapat merangsang timbulnya persepsi awal. Persepsi ini yang akan memberikan timbal balik bagi wisatawan untuk melakukan kunjungan. (Nik Abdul Rahman, 2008) berpendapat jika konsumen mempersepsikan bahwa produk tersebut memiliki keunggulan yang berbeda dengan produk lain dan keunggulan itu sangat berarti bagi konsumen, maka konsumen akan memilih produk tersebut.

\section{Pengaruh Sikap pada Pengambilan Keputusan Berkunjung}

Hasil analisis menunjukan bahwa nilai signifikansi variabel sikap adalah sebesar 0,000. Hal ini menunjukan bahwa sikap berpengaruh positif dan signifikan pada pengambilan keputusan berkunjung. Sikap adalah kecenderungan untuk secara konsisten memberikan tanggapan menyenangkan atau tidak menyenangkan terhadap suatu objek. Tanggapan ini timbul akibat proses belajar atau hasil dari proses evaluasi (Ajzen \& Fishbein, 1970). Berdasarkan atas jawaban responden, mayoritas responden menyatakan bahwa yang bersangkutan kerap melihat promosi daya tarik objek wisata Museum Neka. Responden menyatakan tertarik pada benda kesenian serta fasilitas yang ditawarkan oleh Museum Neka serta mudahnya akses ke lokasi tersebut. Pernyataan ini tentu telah didukung dengan proses evaluasi wisatawan terhadap lokasi wisata. Setelah wisatawan mendapatkan gambaran lengkap mengenai suatu tempat sebagai tujuan wisata, maka yang bersangkutan akan mulai menentukan apakah menyukai atau tidak menyukai produk yang ditawarkan. Perasaan yang ditunjukkan secara konsisten terhadap produk tertentu menunjukkan sikap konsumen. sehingga pada akhirnya melakukan keputusan untuk berkunjung ke suatu obyek wisata.

\section{Pengaruh Pembelajaran pada Pengambilan Keputusan Berkunjung}


Hasil analisis menunjukan bahwa nilai signifikansi variabel pembelajaran adalah sebesar 0,558. Hal ini menunjukan bahwa pembelajaran tidak berpengaruh signifikan pada pengambilan keputusan berkunjung. Hasil penelitian ini berbeda arah dengan temuan dari penelitian yang dilakukan oleh (Masni Nistari et al., 2016) menemukan hasil bahwa pembelajaran berpengaruh secara parsial terhadap keputusan berkunjung. Pembelajaran merupakan suatu proses seseorang yang didapatkan dari pengalaman dan pengetahuan dalam membeli dan menggunakan suatu barang atau jasa. Pembelajaran dapat dijadikan sebagai suatu dasar bagi seorang wisatawan untuk melakukan pengambilan keputusan. Pengetahuan dan pengalaman yang didapatkan tidak hanya berasal dari diri sendiri melainkan dapat berasal dari orang atau wisatawan lain. Hal ini terjadi salah satunya akibat wisatawan berkunjung dengan motivasi untuk melakukan proses belajar dan penelitian. Kondisi ini dibuktikan dengan banyaknya jumlah wisatawan yang berasal dari berbagai sekolah dan universitas untuk melakukan pembelajaran di obyek wisata ini. Para wisatawan tetap melakukan keputusan berkunjung tanpa memperhatikan pengalaman terdahulu baik yang dirasakan oleh yang bersangkutan atau yang dirasakan oleh wisatawan lain.

\section{Pengaruh Kepribadian pada Pengambilan Keputusan Berkunjung}

Hasil analisis menunjukan bahwa nilai signifikansi variabel kepribadian adalah sebesar 0,000. Hal ini menunjukan bahwa kepribadian berpengaruh signifikan pada pengambilan keputusan berkunjung. Hasil penelitian ini searah dengan temuan dari penelitian yang dilakukan oleh (I. Adhi et al., 2016) menemukan hasil bahwa kepribadian berpengaruh secara signifikan terhadap keputusan berkunjung. (Alwisol, 2014) menyatakan bahwa kepribadian adalah sifat umum berupa pikiran, kegiatan, dan perasaan yang berpengaruh secara sistemik terhadap keseluruhan tingkah laku seseorang. Kepribadian seseorang dapat menentukan kecenderungan dalam memilih sesuatu produk atau jasa (I. Adhi et al., 2016). Jika wisatawan lebih suka terhadap suatu lokasi dan akan bertahan pada lokasi wisata yang telah terbukti memberikan kepuasan. Akhirnya kecenderungan konsumen akan berpengaruh terhadap keputusan

\section{SIMPULAN DAN SARAN}

\section{Simpulan}

Hasil penelitian menunjukan bahwa variabel motivasi, persepsi, sikap, dan kepribadian berpengaruh positif dan signifikan pada keputusan berkunjung wisatawan. Berbeda dengan 
variabel pembelajaran yang tidak berpengaruh signifikan pada keputusan berkunjung wisatawan.

\section{Saran}

Penelitian selanjutnya disarankan menambahkan instrumen pada kuesioner berupa pertanyaan mengenai darimana sumber informasi wisatawan mengenai obyek wisata yang akan dikunjungi serta tanggapan wisatawan ketika telah melakukan kunjungan wisata. Hal ini diyakini penting untuk mendukung interpretasi atas hasil penelitian. Penelitian selanjutnya dapat menggunakan variabel independent lain untuk mengetahui faktor-faktor lain yang mempengaruhi keputusan berkunjung wisatawan.

\section{BIBLIOGRAPHY}

Adhi, I., Np, M., \& Shanti, P. (2016). Pengaruh Faktor Psikologis Terhadap Keputusan Berkunjung (Survei Pada Pengunjung Batu Secret Zoo Jawa Timur Park 2). Jurnal Administrasi Bisnis S1 Universitas Brawijaya.

Ajzen, I., \& Fishbein, M. (1970). The Prediction Of Behavior From Attitudinal And Normative Variables. Journal Of Experimental Social Psychology. Https://Doi.Org/10.1016/00221031(70)90057-0

Alwisol. (2014). Psikologi Kepribadian (Edisi Revisi). In Umm Press.

Amirullah. (2002). Perilaku Konsumen (Edisi Pert). Graha Ilmu.

Baron, R. A., \& Byrne, D. (2005). Psikologi Sosial (Edisi 10). Jakarta: Erlangga.

Christine Pratama, A., Sasrawan Mananda, I. G., \& Sudarta, I. N. (2016). Karakteristik, Motivasi Dan Aktivitas Wisatawan Asia Di Kelurahan Ubud. Jurnal Ipta. Https://Doi.Org/10.24843/Ipta.2016.V04.I01.P08

Erna, F. (2008). Merek Dan Psikologis Konsumen Impikasi Pada Strategi Pemasaran. Jurnal Manajemen Dan Kewirausahaan.

Feist, J., \& Feist, G. J. (2013). Theories Of Personality Seventh Edition. Journal Of Chemical Information And Modeling.

Husaen H, Muhammad A., Dan J. (2015). Faktor-Faktor Yang Mempengaruhi Keputusan Wisatawan Dalam Melakukan Kunjungan Wisata Di Kota Tidore Kepulauan. Naskah Publikasi. Jurusan Manajemen Keuangan. Fakultas Ekonomi, Universitas Hasanudin, Makassar.

Inkky Arista, Darsiharjo, Dan S. M. (2017). Pengaruh Produk Wisata Terhadap Keputusan Berkunjung Wisatawan Di Pulau Lengkuas, Belitung. Jurnal Manajemen Resort Dan Leisure. Https://Doi.Org/10.17509/Jurel.V14i1.8433

Kotler, P., \& Keller, K. L. (2009). Manajemen Pemasaran Jilid 1. In Jakarta.

Maduka, C. E., \& Okafor, O. (2014). Effect Of Motivation On Employee Productivity: A Study Of Manufacturing Companies In Nnewi. International Journal Of Managerial Studies And Research.

Masni Nistari, N. P., Sudana, I. P., \& Sasrawan Mananda, I. G. (2016). Pengaruh Faktor Psikologis Terhadap Keputusan Berkunjung Wisatawan Mice Melalui Pt. Y\&R Ke Bali. Jurnal Ipta, 4(2), 11. Https://Doi.Org/10.24843/Ipta.2016.V04.I02.P03

Muksin, D. R. M., \& Sunarti. (2018). Pengaruh Motivasi Terhadap Keputusan Berkunjung Wisatawan Di Ekowisata Mangrove Wonorejo Surabaya. Jurnal Administrasi Bisnis (Jab) $\mid$ Vol.55. 
Nik Abdul Rahman, N. S. (2008). A Practical Guide To Interviewing In Educational Research. Selangor: Centre To Teaching And Learning, Instead, Iium.

Schiffman, L. G., Kanuk, L. L., \& Hansen, H. (2012). Consumer Behaviour: A European Outlook. In Pearson Education.

Solomon, M. R. (2012). Consumer Behavior: Buying, Having, Being. In Consumer Behavior.

Swastha, B., \& Handoko, T. H. (2000). Manajemen Pemasaran: Analisa Perilaku Konsumen. Bpfe, Yogyakarta.

Undang-Undang Republik Indonesia, N. 10 T. 2009. (2009). Undang-Undang No 10 Tahun 2009 Tentang Kepariwisataan. Bifurcations.

Uno, B. H. (2010). Theory Of Motivation And Its Measurement Analysis In The Field Of Education (Teori Motivasi Dan Pengukurannya Analisis Di Bidang Pendidikan). In Bumi Aksara.

Wahyuni H., Yusri Abdillah, Dan S. P. (2015). Pengaruh Faktor Internal Psikologis Wisatawan Terhadap Pengambilan Keputusan Tempat Menginap (Survei Pada Wisatawan Yang Menginap Di Kertanegara Premium Guest-House Kota Malang). Jurnal Administrasi Bisnis, Vol 28, No.1: 123-130, 28, No.1:

Yoeti, A. O. (1996). Pengantar Ilmu Pariwisata. Bandung: Angkasa. 